\title{
European Journal of
}

Business and Strategic Management (EJBSM)

CORPORATE AGGRESSION: A COMPREHENSIVE REVIEW OF PRICE WAR

Asst. Prof. Dr. Ahlam Alzoubi 


\title{
CORPORATE AGGRESSION: A COMPREHENSIVE REVIEW OF PRICE WAR
}

\author{
Asst. Prof. Dr. Ahlam Alzoubi \\ Emirates Aviation University, Dubai \\ Corresponding Authors Email : eaus355@eau.ac.ae
}

\begin{abstract}
Purpose: Despite the significance that prices take in companies, it appears that this factor has not researched extensively by academics and marketers. Therefore, this article investigates price war to provide a comprehensive reference about it.

Methodology: The researcher has conducted an extensive study of the available relevant literature about the price wars. Marketing research and empirical studies from marketing, industrial organizations and economics has provided the framework for this research.

Findings: It is essential to employ appropriate analytic tools for strategic planning of price war. Smart management, along with technical skills, experience and leadership work together for organizational success.

Contribution: This study is significant for compiling a wide range of analytical tests and suggesting their appropriate use on right time. This study is helpful for the companies as it has not only provided step by step strategic planning for price wars but has explained when and how to start price wars.
\end{abstract}

Key words: Pricing, strategic planning, attack. 


\subsection{INTRODUCTION}

From the excess supply of products to aggressive competitors' response there could be multiple reasons for price wars. Heil \& Helsen, (2001) agree that industry structures and strategy affecting events may increase the probability of price wars. Despite any causes of price wars it could have many negative effects if appropriate analysis and strategies are not selected by the company. The company will have to face decline in profits, financial reserves and morale of the workforce. the risk of direct negative financial mostly arises (Nagle, Hogan, \& Zale, 2016). Other side effects of price wars are higher prie senstivity in the customers. When customers are accustomed to obtain required quality, later on increase in the prices would be a hard blow to the expectations of the customers and they may divert to other companies moreover, when price is given priority, brand loyalty is at risk.

Yannopoulos, (2011) categorized strategies into two main groups, the defensive and offensive strategies. The offensive strategies also known as aggressive strategies consist of several strategies including predatory strategies. An essential part of predatory strategies is the price war wherein a firm is in a secure position to trigger it to acquire more market shares, weakening or eliminating competitors, and/or to block market entry against new rivals. Price war strategy depends on cutting prices repeatedly to increase competitors' cost or decrease their profit margin to some limit that they can't compete.

A price war is a two staged strategy: firstly, the short termed where predatory firm sacrifices some profit margin and compensate it for the long term. It is a risky strategy unless the predatory firm is preparing for the war and armed with accurate comprehensive strategic analysis. Strategic planning and using proper analytical tools to evaluate competition is a corner stone before launching or defending price war. However, the leadership is mostly unaware when and how to start price wars. Despite availability of various analytical tools, they are not familiar the right time and use of them. Therefore, this article focuses on price war in an attempt to draw comprehensive understanding about it from the planning moment to when and how it is triggered, its consequences, and how to fight it back. (Krämer, Jung, \& Burgartz, 2016; Peinert, 2020; Bhattacharya, 2020) have researched this topic before, but each studied it from a particular perspective. While, this paper tackles the issue from a comprehensive point of view to provide researchers, academics and the CEO`s with concentrated comprehensive reference. In addition, the article proposes an analysis framework before preparatory attack based on best practices and literature on management research.

\subsection{METHODOLOGY}

For in-depth and comprehensive study of the topic, researcher reviewed the body of knowledge available on the topic, with systematic review of the literature. The framework helps the audience to understand the analysis before price wars, its strategic planning and appropriate responses. The article consists of two main parts; first part discusses the required steps before predatory attack, i.e. strategic planning, deploying analytical matrices like SPACE, QSPM, BCG, HHI and Areeda-Turner test to measure market concentration and to reveal predatory pricing respectively. The second part discusses when and how price war is triggered with some 
concentration on the Early Warning Signals (EWS) of Heil \& Helsen (2001). The study would be useful for company management to improve its competitive edge in the market.

\subsection{ANALYSIS BEFORE PREDATORY ATTACK}

Trout, (1997) ensured that companies must not be trapped by the idea that working hard leads to success, but the proper strategy determines the success in a competitive market. This is important to survive where competition is increasing rapidly with complex environmental changes. The most important concern of most companies is formulating successful smart strategy to protect current assets and increase gains in a competitive market.

Radder \& Louw, (1998), Yannopoulos, (2011) specified four type of strategies four types of strategies: aggressive, conservative, defensive and competitive strategies from competitiveness point of view, ensuring that the Strategic Position and Action Evaluation Matrix (SPACE Matrix) is a very useful guide to help deciding which strategy is most appropriate in which situation. The SPACE Matrix assesses the business across four dimensions: Industry Attractiveness (IA), Environmental Stability (ES), Competitive Advantage (CA), Financial Strength (FS).

Companies typically use many strategies concurrently, but market gains made only with an aggressive strategy. Moreover, a successful strategy always takes into consideration the competitors' response. If companies are in a good position, i.e. having a favourable position in all four dimensions and can follow an aggressive strategy as it leverages its strengths into the opportunities available. These actions are differing from company to another, even though they have a good position according to the SPACE matrix.

\section{Strategic planning and competitive position}

Stambaugh, Yu, \& Dubinsky, (2011) raised the question about the firms' strategy before launching competitive attacks. They believed that answers to this question are virtually unknown. Additionally, he propounds that firms have strategic orientations, which drive their strategies, and that they're taking competitive action is consistent with that orientation, support the strategy, and is aimed toward a specific strategic outcome.

Rao, Bergen, \& Davis, (2000) illustrates that before entering the price war battle, an accurate diagnosis must be done involving four main keys: customer sensitivity, i.e. customer issues such as price sensitivity and the customer segments; company issues such as a business cost structure, capabilities, and strategic positioning; competitor issues, such as a rival's cost structure, capabilities, and strategic positioning; and finally the contributor issues, or the other players in the industry.

In view of that, we believe, though a decision to attack rottenly companied with fatal risks; hence; professional strategic planning is needed. Following best practices of management literature, we suggest a flexible framework to carry out professional strategic planning which goes into three main steps; the first is to identify and analyze key strategic factors using both the External Factor Evaluation ( EFE) and Internal Factor Evaluation (IFE) matrices; where EFE the External Factor Evaluation allows strategists to summarize and evaluate economic, social, 
cultural, demographic, environmental, political, governmental, legal, technological, and competitive information; and inputs for EFE import from analyzing the external environment with the tools like Political, Economic, Social and Technological (PEST) analysis, Porter's Five Forces or Competitive Profile Matrix. On the other hand; IFE matrix, i.e. Internal Factor Evaluation reveals the Strengths and weaknesses of the company.

The second step is to recognize the competitive position of the company, and the SPACE analysis is a proper, accurate tool; which was developed by strategy academics Alan Rowe, Richard Mason, Karl Dickel, Richard Mann and Robert Mockler (Beton, 2012). If the analysis output came in favourable positions in all four dimensions, then business can follow an aggressive strategy. However, the competitive position is very crucial, therefore, it is recommended to do more analysis through repeating this step using the modified SPACE matrix (Gurbuz, 2013).

Yannopoulos, (2011) introduced a wide range of strategic approaches that company can follow when SPACE Analysis recommends that business is in a strong position: continue to invest in innovation; respond to any moves made by competitors; aggressively build market share by moving above the fair value line in the customer value map; implement massive marketing campaigns; reducing prices to levels that competitors find difficult to match; grow within the market through acquisitions; follow up on possible opportunities in the market including backward or forward vertical integration.

On the third stage it is necessary to combine appropriate strategies to achieve competitive edge. In this regard, Quantitative Strategic Planning Matrix (QSPM) is a proper approach to select objectively the best strategy while using inputs from step one and two and matching them together using simple calculations (David \& Kovács, 2020). Moreover, BCG matrix or BCG model can also be used for strategic management of price wars. The BCG model is well-known portfolio management tool used in product life cycle theory. BCG matrix is often used to prioritize which products within the company`s product mix get more funding and attention.

\section{Competitive drivers}

Chen, (1995) outlined three drivers for competitive behaviour: awareness, motivation and capability. Stambaugh, Yu, \& Dubinsky, (2011) advanced the idea that awareness, motivation, and capability are manifested as firm processes and suggested that these processes make some firms more competitive aggressive than others. In addition, he ensured that when adopting competitive action, a company may be operating from innovation logic or from a competitively aggressive logic, but usually not both.

\section{Competitor analysis}

In highly concentrated industries Competitors Analysis is an essential component or even vital part for any company. It is an assessment of the current and potential competitors strengths and weaknesses, and an attempt to predict their behaviour and responses. E Porter, (1998) defined a framework to analyze competitors based on their objectives, assumptions, strategy and capabilities. One common and useful technique used in competitor analysis is constructing a competitive array. Engelke, Papadopoulos, Steiner, \& Volkert, (2015) proposed an extensive 
approach for strategist to understand how to gather and analyze information about competitors that is useful in the strategy development process.

In addition, measuring the concentration of the market is essential in competition analysis. Concentrated market is a term used to describe markets where few players with a large percentage of the market according to some specific product. The Herfindahl-Hirschman Index (HHI) is a widely accepted index to measure market concentration. The index is calculated by squaring the (\%) market share of each firm (up to 50 firms) in the market and summing these numbers. It is used as an analytical tool to view the competition structure and to determine if the industry is a competitive or nearing monopoly. A pure monopoly market score is 10,000 i.e. $100^{2}$, therefore, the lower the index, the more competitive the market is, and can reach almost zero for perfect competition. Some merger guidelines consider a market highly concentrated if the HHI exceeds the score 2000; and a market with HHI score 1000 or below is considered competitive. The United States Federal anti-trust authorities such as the Department of Justice and the Federal Trade Commission use the Herfindahl index as a screening tool to determine whether a proposed merger is likely to raise antitrust concerns (Warren-Boulton, 1990)

\section{Professional management}

The CEOs` role is a major key factor in the competition battle. They can reduce risk and increase success. Paese, (2008) ensured that succession is not a decision-it is an ongoing process to diligently foster and drive the growth of internal leadership capability. According to Goldstein, (2013), ambitious CEOs recognize that the only way to stay ahead in the market is to be fairly aggressive.

The other significant factor is talent management. Shrimali \& Gidwani, (2012) consider it a strategic source in today's competitive environment. Harrington, Voehl, \& Voehl, (2014) underline two important principles: firstly, management required skills are technical, leadership and management; secondly, the level of talent management alignment with the organizational strategy has a clear impact on the success of projects meeting their original goals and business intent.

\section{Price War}

The predatory strategies` philosophy is a simple sacrifice with some profit margin in the short term and recoups more profits in the long run. Therefore, predation can be seen as an investment in long-run market power. Predatory strategy consists of two groups of strategies: the first is the predatory pricing strategy or price war, the second group is the non-price strategies which, according to Boudreaux, (1990) consist of Raising Rivals`Cost (RRC), Spatial oligopoly, and Predatory innovation; other researchers give them other names.

Price cuts used mainly to either keep the market share or to acquire new customers and weakening the competitors. Cressman Jr \& Nagle, (2002) said that pricing is like playing chess. Heil \& Helsen , (2001) state that price war effects are most often disastrous and seemingly unsurpassed by any other form of competitive exchange. Rao, Bergen, \& Davis, ( 2000) advise that," best way to escape a damaging price war is not to jump into the fray at all". Henderson, (1997) considers that price wars are good for absolutely nothing. Brandenburger \& Nalebuff, 
(2011) believe that price wars generally hurt revenues and long-term prospects. Zhang \& Zhou, (2010) ensure that Chinese companies do not share the same code of business conduct with western companies. According to Kumar, (2006), "Low-cost players will continue to mushroom, and some will succeed."

Many managers consider cutting prices as little profits better than losing the wholesale. In addition, it is an easy, quick, and reversible action. But it may turn very destructive and unpredictable since cutting prices may end up in bankruptcy, or at least a weak position before entering the arena, or be a hero and a market leader.

\section{When and how to start a price war}

Yannopoulos, (2011) emphasizes that Rivalry occurs because one or more competitor is either feeling the pressure or seeing an opportunity to enter an industry or to improve its position within an industry. Klemperer, (1989) distinguishes between two types of price wars according to the switching costs, i.e. customers have to pay the extra cost for switching between two or more functionally equivalent brands, this cost may be in term of money, such closing an account in a bank and move to another, sometimes the cost will be in term of effort i.e. to learn using technical hardware. Thus, these two types of price war may occur before entry of the market to lock competition, or during entry.

Bresnahan, (1987) distinguish between competitive and collusive behaviours of companies. If firms compete on price, price will be near marginal cost of those products for which a close, competitive substitute exists. If firms are setting price by some (tacitly) collusive means, then for one firm`s products shall not depend crucially on whether their close substitutes are sold by competitors or by the firm. Thus, by focusing on the structural supply equation, one can discriminate between competition and collusion. However, he clarified that the price fell during a macroeconomic expansion, quantity increased, and market segment increased.

Nagle \& Cressman Jr, (2002) specified three main reasons to start war prices: first, when the business has a substantial and sustainable cost advantage, second: When a strategic objective of the firm is market share growth regardless of profitability concerns, and the third: when managers do not expect a response. Heil and Helsen (2001) specified four types of factors may trigger price wars, or at least facilitate their ignition and affect their intensity: market, the firm itself, product, and consumer characteristics. They developed an analytical framework calling it the Early Warning Signals (EWS) related to these factors; and they offered a set of propositions to be researched. These propositions can be considered as a cornerstone for any researchers since they are comprehensive and cover almost all situations in which price war may be triggered, though we consider listing them is necessary. The propositions are: 
European Journal of Business and Strategic Management

ISSN 2518-265X (Online)

Vol.5, Issue 2, No.3. pp 50 - 63, 2020

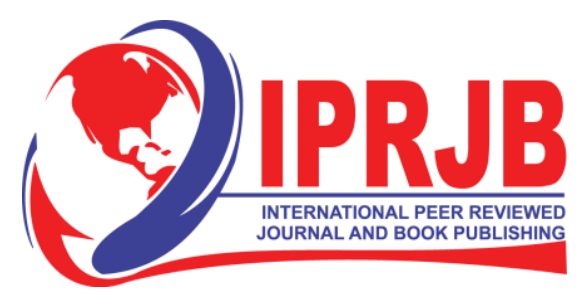

WWw.iprib.org

\begin{tabular}{|c|c|}
\hline & Propositions \\
\hline \multicolumn{2}{|r|}{ Market propositions $(P 1)$} \\
\hline 1a. & $\begin{array}{l}\text { As market entry occurs and an entrant gain or is expected to gain a sizable market position, a } \\
\text { price war becomes more likely. }\end{array}$ \\
\hline 1b. & $\begin{array}{l}\text { If an industry possesses the excess capacity, the emergence of price wars is more likely. Excess } \\
\text { capacity will also stimulate the intensity of price warfares when they occur. }\end{array}$ \\
\hline 1c. & $\begin{array}{l}\text { Price wars are more likely to occur and to be more intense in markets with marginal (or } \\
\text { negative) growth. }\end{array}$ \\
\hline $1 \mathrm{~d}$. & $\begin{array}{l}\text { The incidence of price warfares is relatively high in markets where market power is highly } \\
\text { concentrated and fragmented markets and low for markets with intermediate levels of concentration }\end{array}$ \\
\hline \multicolumn{2}{|r|}{ Firm`s propositions $(P 2)$} \\
\hline $2 \mathrm{a}$. & As the exit barriers increase, the likelihood of price wars grows as well. \\
\hline $2 \mathrm{~b}$. & $\begin{array}{l}\text { Price wars are less likely to emerge in markets where a single firm is viewed as being the price } \\
\text { leader. }\end{array}$ \\
\hline $2 c$. & $\begin{array}{l}\text { Price wars are less likely to emerge in markets where one (or more) firm(s) have established a } \\
\text { strong reputation for toughness by combating past deviations. If price wars emerge in markets with one } \\
\text { (or more) high reputation firm(s), the resulting price Warfare tends to be more intense than in other } \\
\text { markets. }\end{array}$ \\
\hline $2 \mathrm{~d}$. & As financial conditions of at least one firm in an industry worsen, price wars are more likely to \\
\hline 2e. & As a firm approaches bankruptcy, the likelihood of price wars in an industry increases \\
\hline \multicolumn{2}{|r|}{ Product propositions (P3) } \\
\hline 3a. & $\begin{array}{l}\text { The higher a product's strategic importance to a company, the higher the likelihood of a price } \\
\text { ar. }\end{array}$ \\
\hline $3 b$. & The more commodity- like the products in a market, the more likely a price war. \\
\hline $3 \mathrm{c}$. & The introduction of head-to-head products increases the likelihood of a price war. \\
\hline \multicolumn{2}{|r|}{ Consumer's propositions $(P 4)$} \\
\hline 4a. & The lower the brand loyalty in a market, the more likely an outbreak of a price war \\
\hline 4b. & $\begin{array}{l}\text { The higher consumers' price sensitivity, the higher the likelihood and intensity of price } \\
\text { warfares }\end{array}$ \\
\hline
\end{tabular}

On the other hand; Zhang and Zhou (2007), clarified that companies (by putting aside any longterm benefits or costs) can benefit in the short term if its sales go up sufficiently. To determine the threshold sales increase that is needed for a firm to benefit from a price cut, one can conduct the so-called incremental breakeven analysis; the Incremental Breakeven Analysis (IBEA) which is a tool used to assess planning for the price war. This analysis is based on an equation:

$\Delta q=[\Delta p-(1-\mathrm{cm}) \Delta c] /[\mathrm{cm}-\Delta p+(1-\mathrm{cm}) \Delta c]$

Where:

$\Delta q$---the breakeven sales increase in percentage;

$\Delta p$---the magnitude of a price cut; 
$\mathrm{cm}$---the contribution margin in percentage (before the price cut);

$\Delta c$---the reduction in marginal costs in percentage due to the price cut.

Therefore; according to the IBEA to benefit from a deep price cut, a firm must generate enough sales increases to cross the threshold of $\Delta q$. Where does this sales increase come from?

Zhang and Zhou (2007) answer this question trough sales change will come from either its market share change, or the industry demand change, or both since $\Delta q=\Delta s+\Delta Q+\Delta s \Delta Q$, where $\Delta s$ is the change in the firm's market share in percentages and $\Delta Q$ is the change in the industry demand in percentages.

Concerning the proper moment to launch price war, Zhang and Zhou (2007) answer this question again through determining suitable situations: First, it is easier for a firm with a small initial market share to increase it, a small market share firm is better positioned to use price as a weapon and to initiate a price war, and a big market share firm may want to think twice about it; Chen and Hambrick (1995) found the same result, that small firms tend to attack more often, but large firms are more likely to respond when attacked.

Second, the timing of starting a price war is very critical. A firm has a better chance to increase its market share if competition is unable or unwilling to react swiftly. Third, even if competition reacts swiftly by bringing down their own prices, an astute firm can still increase its market share if it has prepared for a price war adequately through building up its inventories, ramping up its productions, and boosting up its production capabilities, will be best positioned to increase its market share. Fourth, a firm can gain a larger market share when less cost-effective firms in an industry are eliminated or weeded out. On the long-term companies assess the benefits or losses from a price war in terms of its impact on the future cash flows, and they can adjust $\Delta q$ downward or upward accordingly.

\section{How to detect predatory prices}

Detecting price war or predatory prices is too multifaceted a phenomenon to be identified. Nevertheless, there are price-cost tests used to know if a firm has a cost competitive advantage to sell products at prices lower than the competitors or the predatory firm is selling below its cost to eliminate competitors and establish an entry barrier. The most common price-cost tests are: the marginal cost test (MC), average variable cost (AVC), average avoidable cost (AAC), average total cost (ATC). But the most commonly used is the Areeda-Turner Test which is named after the coauthors (Areeda \& Hovenkamp, 2011). Hovenkamp, (2015) said: "no one has been able to come up with something better".

Areeda-Turner test proposes that prices below the MC are predatory, and AVC can be used as a proxy of the MC. If the price is above ATC, then the firm is making profits on all consumers or markets, and exclusion should be dismissed. The grey area is when the price is between AVC and ATC. Hence; in some cases, it is really difficult to distinguish between predatory prices and competitive prices. 
European Journal of Business and Strategic Management

ISSN 2518-265X (Online)

Vol.5, Issue 2, No.3. pp 50 - 63, 2020

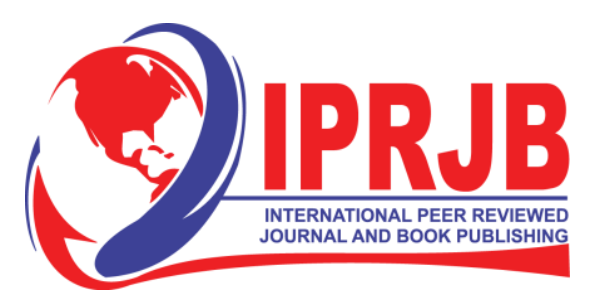

www.iprib.org

\section{Respond to price war}

There is no unified form of response, but there are analytical principles to follow. Engaging in a price war with no accurate evaluation may harm the company itself more than the competitors' actions. Cressman Jr \& Nagle, (2002) set two principles the first, a company may engage in the battle if it can win and the second is using its competitive advantage or strength. In addition, they developed a decision chart starting from evaluating the threat and lying down questions about the risk level per situation and suggest a corresponding solution. The solutions are either: to neglect, partially respond, accommodate and respond aggressively.

Akshay R. Rao, Mark E. Bergen, and Scott Davis (2000), propose two set of actions; non-price responses, e.g. compete on quality, reveal the cost advantage, form strategic partnerships with suppliers, retailers, etc.; and price response e.g. simple or complex price deployment, or introduce new products. Kumar (2006), set up a framework to respond to low cost rivals; this framework consists of situations with correspondent advice vary from watching, differentiate products, restructuring, merge with rivals or takeover, attack, and finally switch to the low-cost model if possible.

Finally, there will be all the time customers seeking low prices and others appreciate the product value. Therefore, the market has flexibility for different types of players, but the company with the smart, proper, strategy will have a higher chance to survive. Therefore, the recommendation about the proper response to war price is to carry out quick, accurate, comprehensive quantitative evaluation of the threat and analyze all related factors (e.g. Cost advantage, customer sensitivity, switching cost, etc.), and list all rational possible alternatives and pick up the most suitable one. In some situations, response may cost more than losing some market share, or a company may make benefit from existing weak competitor involving in a cutting price process better than destroying him, simply because there is a chance that a solvent investor may acquire it, and engage with tough price war cut. Therefore, the technical skills, experience and leadership play a vital role in this field.

\section{Techniques if can't win a price war}

In some situations; a company may realize that they can`t win the price war. Hence, they try to apply product differentiate strategy including innovation, design cool products, unique offer mix, brand the market segment or turn to sell an experience and abandoning selling products (Kumar, 2006). He ensures smart businesses don't use these tactics in isolation, and companies must be able to persuade consumers to pay for benefits and bring costs and benefits in line together.

Businesses have a good chance to overcome price war since it has other weapons through differentiating the product and the service, according to many factors such as quality, marketing, online selling, quick delivery, friendly web site, packaging, ethics, strategic partnerships, etc. The secret in this situation is a mixture of talent, skill, leadership to use the proper combination of these tools to have competitive advantage based on quality and service and freeze the price. Ikea the famous furniture manufacture adopts a simple approach which is offering cheap but high-quality products using two main advantages; the first sourcing its products in low wage countries; second, they don`t assembly their products (KOBAYASHI). 
European Journal of Business and Strategic Management

ISSN 2518-265X (Online)

Vol.5, Issue 2, No.3. pp 50 - 63, 2020

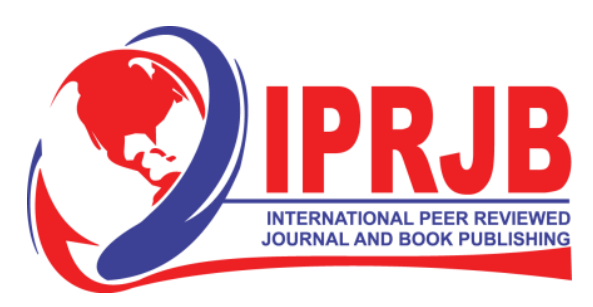

WWW.iprjb.org

\section{Consequences of price war}

Van Heerde, Gijsbrechts, \& Pauwels, (2005) in their analysis of retail price wars in Dutch grocery retailing estimated the one-year loss in the added value at euro 900Millions for retailers and suppliers, and 30,000 employees lost their jobs and smaller companies are on the verge of bankruptcy.

Antwi, (2011) concluded in the research "The effect of the telecommunication price war on consumers in the Kumasi Metropolis", that the overall research findings have established that price war benefits no one, not even the consumer. Consumers become more price-sensitive and less brand loyal, margins are squeezed across the board, and the customer-experience ultimately gets worse.

Akshay R. Rao, Mark E. Bergen, and Scott Davis (2000), gave a straightforward example of the consequences of price war; it is the airline price wars of 1992. When American Airlines, Northwest Airlines, and other U.S. carriers went "toe-to-toe" in matching and exceeding one another's reduced fares, the result was overall losses in that year exceed the combined profits for the entire industry from its inception.

Heil, Oliver P and Kristiaan Helsen (2001) mentioned an extreme case, price warfare may lead to a restructuring of distribution channels, like laser printer industry, a price war stimulated a shift in distribution channels from traditional resellers to superstores and consumer electronic stores.

Dr. Peter Yannopoulos (2011), add that price cuts may run the risk of inviting government intervention. Although predatory pricing is illegal, and he ensures that it is extremely difficult to distinguish between anti-competitive pricing behaviours from a genuine pricing strategy based on low margins.

On the other hand, where, war prices may lead to remarkable success, Zhang and Zhou (2007), explained in details the success story of two Chinese companies, "Changhong" a coloured T.V Chinese manufacturer used cost advantage efficiently, huge inventory and war price to increase its overall market share from $16.68 \%$ to about $35 \%$. The second company is "Galanz", a microwave oven manufacturer, from August 1996 till October 2000; Galanz initiated five major price wars and became the world's largest microwave oven manufacturer, with about $30 \%$ of the worldwide market and $76 \%$ of the Chinese market.

\section{Phoney price wars \& price match guarantee}

Retail business, especially the supermarkets may use two techniques to increase revenue: the first is the phoney price war; the approach very simple, but smart, lower prices of high velocity products increase others; and lower with extra margin few products which its prices are very known to customers; companying this action with a marketing campaign. Hickman, (2009) wrote in The Independent (UK newspaper) about three famous retail businesses in the UK, In the last five years, Tesco's UK operating profit margin has risen from 5.7 per cent to 6.7 per cent. Over the same period, Sainsbury's operating profit has risen from 2.07 per cent to 3.26 per cent, while pre-tax profit at Morrison's has leapt from 1.59 per cent to 4.51 per cent. The question how these retailers engaged in war prices and all of them gained extra profits. 
The second technique is price match guarantee, which is known as cartel pricing from economics and anti-trust point of view; since it is believed that it facilitates monopoly and establishes an entry barrier for rivals. This conclusion is derived using rational logic; when competitors announce match price guarantee there is no incentive to lower it more because firms have effectively colluded to keep prices high. In addition, price match guarantee may boost consumer confidence and brand loyalty.

On the other hand, Moorthy \& Winter (2002) concluded that the "collusive pricing result under symmetric and somewhat asymmetric cost structures arises not just as a Nash equilibrium, but as a dominant strategy equilibrium; on the other hand that only a low-cost firm would use pricematching under conditions of significant cost disparities, and that the resulting pricing is more competitive than collusive, weakens the collusion argument".

Hviid \& Shaffer (1999) are the first who considers Hassel costs; when examining the competitive effects of price-matching guarantees, and they proposed a model to explain why some firms adopt price matching guarantee and other firms not; they concluded that price-matching guarantees may arise for reasons other than the collusive rationale or may arise from pricediscrimination purposes or may alter consumer search behaviour to the benefit of the price matcher. Their research paper is a reference source for researchers.

However, the price guarantee match is not considered by many researchers and CEO's as a strategy; since it is not guaranteed approach to increase sales or success, in addition; it doesn't focus on consumers` needs or wants.

\section{Antitrust regulation}

Markets become more and more global, trade and market are crossing national borders, so most countries of the world regulated competition by issuing antitrust law, this is very essential for every country, antitrust or competition law set the legal basis for protecting consumers, preventing monopolies and cartels, and promoting investments.

United States, UK, EU and OECD countries and almost a majority of developing countries are regulating competition by laws or acts. The implementation may vary from a country to another, but there are many organizations offer support and technical advisory to countries to follow best practices.

The International Competition Network (ICN) is an informal, virtual network that seeks to facilitate cooperation between competition law authorities globally. It was established in 2001, The ICN is unique as it is the only international body devoted exclusively to competition law enforcement and its members represents national and multinational competition authorities. ICN publishes the periodically Global Competitiveness Index with other antitrust guidelines and research publication

\subsection{CONCLUSION AND RECOMMENDATION}

\section{Conclusion}

Strategic planning and updated market analysis are necessary for every firm, but it's not adequate; smart management armed with proper technical skills, experience and leadership are 
the successful key; since they can predict market changes and make use of every opportunity to increase their market share by deploying proper strategy depending on maximum use of their competitive advantages.

A Price war is a fact; some firms suffering from it, others make gains. In this life where survival depends on smartness, capability, awareness, motives, experience, quick rational response and the technical and adaptation skills; firms need to enhance their analytical capacity by using different tools to reveal and observe tactics of the rivals, including price wars; firms who wake up lately will lose much. The article attempts to include all related and needed technical tools with adequate illustration on links between it. In addition; it summarizes all the propositions in which price war may be triggered.

\section{Recommendations}

On the basis of this comprehensive study, it is recommended that before waging price wars the company should define a strategic planning with the use of appropriate analytical tools. The evaluation of threats and other relevant factors like cost advantage, customer sensitivity, switching cost etc. can lead to all rational possible alternatives and the leadership can select the most appropriate one. The process of price wars is consisted of three stages. Firstly, the company should conduct an Internal Factor Evaluation (IFE) and External Factor Evaluation (EFE) to calculate the existing position of the company with all its strengths and weaknesses. Secondly, to analyze the competitive position of the company. on the third stage, it should select appropriate strategies in light of finding in step one and two.

Substantial financial advantage, market share growth, and unresponsive customers are the conditions when a company can think to start a price war. For starting a price war, AreedaTurner test is best to detect predatory price. A company can choose either non-price responses or price response according to its strategic position in the market. If a company fails in price wars it can opt for other options like new product or unique offer mix. Though, for competitive advantage the price wars are started but empirical studies reveal that it has more negative influence than positive.

\section{Bibliography}

Antwi, E. (2011). The Effect of Telecommunication Price War on Consumers in the Kumasi Metropolis (Doctoral dissertation).

Areeda, P. \&., \& Hovenkamp, H. (2011). Fundamentals of antitrust law (Vol. 10). Aspen Publishers Online.

Beton, M. (2012). Application of SPACE Matrix. . Developing Country Studies, 8, , 50-60.

Bhattacharya, R. R. (2020). Short-run constraints and price wars.

Boudreaux, D. J. (1990). Turning Back the Antitrust Clock: Nonprice Predation in Theory and Practice. . Regulation, , 13, 45.

Brandenburger, A. M., \& Nalebuff, B. J. (2011). Co-opetition. Currency. 
European Journal of Business and Strategic Management

ISSN 2518-265X (Online)

Vol.5, Issue 2, No.3. pp 50 - 63, 2020

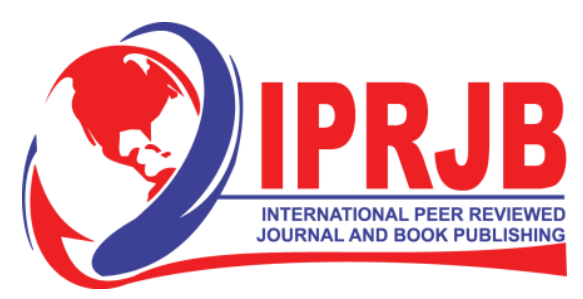

www.iprib.org

Bresnahan, T. F. (1987). Competition and collusion in the American automobile industry: The 1955 price war. . The Journal of Industrial Economics, , 457-482.

Chen, M. J. (1995). Competitive analysis and inter-firm rivalry: Toward a theoretical integration. . Academy of Management Journal, 7.

Cressman Jr, G. E., \& Nagle, T. T. (2002). How to manage an aggressive competitor. . Business Horizons, 45(2), , 23-30.

David, F. \&., \& Kovács, T. (2020). Introducing QSPM Analysis to Agribusiness Firms. sa55, 158.

David, M. E., David, F. R., \& David, F. R. (2009). The Quantitative Strategic Planning Matrix (QSPM) applied to a retail computer store. The Coastal Business Journal, 8(1), , 42-52.

E Porter, M. (1998). Competitive Strategy: Techniques for analyzing industries and competitors.

Engelke, C., Papadopoulos, G., Steiner, I. \&., \& Volkert, N. M. (2015). Mini-project-Module 1b Autumn.

Goldstein, A. P. (2013). United States: Causes, controls, and alternatives to aggression. . Aggression in Global Perspective: Pergamon General Psychology Series, , 115, 435.

Gurbuz, T. (2013). A Modified Strategic Position and Action Evaluation (SPACE) Matrix Method. . In Proceedings of the International MultiConference of Engineers and Computer Scientists (Vol. 2).

Harrington, H. J., Voehl, F. \&., \& Voehl, C. F. (2014). Model for.

Heil, O. P., \& Helsen, K. (2001). Toward an understanding of price wars: Their nature and how they erupt. . International Journal of Research in Marketing, 18(1-2), , 83-98.

Heil, O. P., \& Helsen, K. (2001). Toward an understanding of price wars: Their nature and how they erupt. . International Journal of Research in Marketing, 18(1-2), , 83-98.

Henderson, D. R. (1997). Best practices-What are price wars good For? Absolutely nothing.

Hickman, M. (2009). Bad service and grumpy Britons put tourism jobs at risk. . Guardian.

Hovenkamp, H. (2015). The Areeda-Turner test for exclusionary pricing: A critical journal. . Review of Industrial Organization, 46(3), , 209-228.

Hviid, M. \&., \& Shaffer, G. (1999). Hassle costs: the Achilles' heel of price- matching guarantees. . Journal of Economics \& Management Strategy, 8(4), , 489-521.

Klemperer, P. (1989). Price wars caused by switching costs. The Review of Economic Studies, 56(3), , 405-420.

KOBAYASHI, S. (n.d.). Secret behind IKEA’s pricing strategy.

Krämer, A., Jung, M. \&., \& Burgartz, T. (2016). A small step from price competition to price war: understanding causes, effects and possible countermeasures. International Business Research, 9(3), , 1-13.

Kumar, N. (2006). Strategies to fight low-cost rivals. Harvard business review, 84(12), , 104-12. 
European Journal of Business and Strategic Management

ISSN 2518-265X (Online)

Vol.5, Issue 2, No.3. pp 50 - 63, 2020

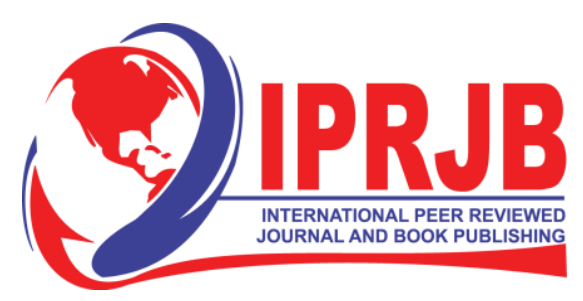

WWw.iprib.org

Moorthy, S. \&., \& Winter, R. A. (2002). Price-matching guarantees. Review of Marketing Science (ROMS) Working Paper.

Nagle, T. T., \& Cressman Jr, G. E. (2002). Don't just set prices, manage them. Marketing Management, 11(6), 29.

Nagle, T. T., Hogan, J. \&., \& Zale, J. (2016). The Strategy and Tactics of Pricing: New International Edition. Routledge.

Paese, M. J. (2008). Your next CEO: Why succession planning is more important than ever. . In The Conference Board Review (Vol. 45, No. 6, 18-23.

Peinert, E. (2020). Cartels, competition, and coalitions: the domestic drivers of international orders. Review of International Political Economy, , 1-25.

Radder, L. \&., \& Louw, L. (1998). The SPACE matrix: A tool for calibrating competition. Long range planning, 31(4), , 549-559.

Rangnekar, A. (2018). The Evolution of Marketing and Strategic Thought. . Chetana's, 1.

Rao, A. R., Bergen, M. E., \& Davis, S. (2000). How to fight a price war. . Harvard Business Review, 78(2), , 107-120.

Rao, A. R., Bergen, M. E., \& Davis, S. (2000). How to fight a price war. . Harvard Business Review, 78(2),, 107-120.

Shrimali, H. \&., \& Gidwani, B. (2012). Role of talent management in sustainable competitive advantage: Rising to meet business challenge. Pacific business review international, 4(3), , 29-33.

Stambaugh, J. E., Yu, A. \&., \& Dubinsky, A. J. (2011). Before the attack: a typology of strategies for competitive aggressiveness. . Journal of Management Policy and Practice, 12(1), 49.

Trout, J. (1997). The new positioning: the latest on the world's\# 1 business strategy. McGraw Hill Professional.

Van Heerde, H. J., Gijsbrechts, E. \&., \& Pauwels, K. (2005). Price war: what is it good for? Store incidence and basket size response to the price war in dutch grocery retailing. . Tilburg University, LE Tilburg, The Netherlands.

Warren-Boulton, F. R. (1990). Implications of US experience with horizontal mergers and takeovers for Canadian competition policy. The law and economics of competition policy. Vancouver, BC.

Yannopoulos, P. (2011). Defensive and offensive strategies for market success. . International Journal of Business and Social Science, 2(13).

Zhang, Z. J., \& Zhou, D. (2010). The Art of Price War: A Perspective From China. . International Journal of China Marketing, 1(1), , 17-30. 